\title{
Cytotoxicity of Different Composite Resins on Human Gingival Fibroblast Cell Lines
}

\author{
Riccardo Beltrami ${ }^{1, *}$, Marco Colombo ${ }^{1, \dagger}{ }^{,}$Keren Rizzo ${ }^{1}$, Alessio Di Cristofaro ${ }^{2}$, Claudio Poggio ${ }^{1, *(D)}$ \\ and Giampiero Pietrocola ${ }^{2}$ (D)
}

1 Department of Clinical-Surgical, Diagnostic and Pediatric Sciences-Section of Dentistry, University of Pavia, 27100 Pavia, Italy; marco.colombo@unipv.it (M.C.); keren.rizzo01@universitadipavia.it (K.R.)

2 Unit of Biochemestry, Departement of Molecular Medicine, University of Pavia, 27100 Pavia, Italy; alessiodc-94@hotmail.it (A.D.C.); giampiero.pietrocola@unipv.it (G.P.)

* Correspondence: rbreferee@gmail.com (R.B.); claudio.poggio@unipv.it (C.P.)

+ This author is senior author.

Citation: Beltrami, R.; Colombo, M.; Rizzo, K.; Di Cristofaro, A.; Poggio, C.; Pietrocola, G. Cytotoxicity of Different Composite Resins on Human Gingival Fibroblast Cell Lines. Biomimetics 2021, 6, 26 https://doi.org/10.3390/

biomimetics6020026

Academic Editor: Josep Samitier

Received: 20 March 2021

Accepted: 15 April 2021

Published: 20 April 2021

Publisher's Note: MDPI stays neutral with regard to jurisdictional claims in published maps and institutional affiliations.

Copyright: (C) 2021 by the authors. Licensee MDPI, Basel, Switzerland. This article is an open access article distributed under the terms and conditions of the Creative Commons Attribution (CC BY) license (https:/ / creativecommons.org/licenses/by/ $4.0 /)$.

\begin{abstract}
The aim of the present study was to evaluate and compare the cytotoxic effects of eight composite resins on immortalized human gingival fibroblasts. Composite resins were eluted in cell culture medium for 48 or $72 \mathrm{~h}$ at $37^{\circ} \mathrm{C}$. Immortalized human gingival fibroblast-1 (HGF-1) cell lines were seeded in 96-well $\left(1 \times 10^{4}\right)$ plates and incubated for $24 \mathrm{~h}$ at $37^{\circ} \mathrm{C}$ with the obtained extraction medium. The percentage of viable cells in each well (MTT test) was calculated relative to control cells, which were set to $100 \%$. Data observed were not normally distributed, and nonparametric statistical methods were used for statistical analysis. The Wilcoxon test was used for intragroup comparison, and the Kruskal-Wallis test was used for intergroup multiple comparisons. Significance value was set as $p<0.05$. All materials tested showed cytotoxic effects on gingival fibroblasts, recordable as noncytotoxic, mildly cytotoxic or severely cytotoxic, depending on the percentage of cell viability. The Wilcoxon test for intragroup comparison showed that the percentage of viable cells decreased significantly for extracts, for all composite resins tested. The composite resins contained monomers that displayed cytotoxic properties. BisGMA, TEGDMA and UDMA had inhibitory effects and induced apoptotic proteins in pulp fibroblast. Composite resins that contained lower percentages of unbound free monomers-and that released less ions-possessed superior biocompatibility in vitro.
\end{abstract}

Keywords: cytotoxicity; gingival fibroblast; MTT test; composite resins

\section{Introduction}

Composite resins are used extensively as restorative materials in conservative dentistry because of their ideal mechanical properties and desirable aesthetics. However, their use requires specific focus on the safety of the components used [1-3]. Over the last twenty years, resin composites have been developed in order to reduce cytotoxicity and polymerization shrinkage and improve aesthetics [1,2]. The biocompatibility of composites is an issue that requires particular attention to be paid to the chemistry of the biopolymers from which they are made [3]. Innovative resin composites are composed of a polymerizable organic resin matrix and a particulate ceramic reinforcing filler. These two main components are connected by a silane coupling agent [4]. The attention on biocompatibility is focused mainly on the polymerizable organic resin matrix. Among the components of the composite resins, the resin matrix is the only unstable one-primarily because of the unbound monomers that could be released. One study [3] stated that $15-50 \%$ of the methacrylic groups in the organic matrix remained as free monomers during the polymerization phase [5]. The amount of organic resin matrix used has been reduced over time. Composite resins have now evolved from hybrid polymers to organically modified ceramic materials (ormocers). Recent studies [6,7] on ormocers reported unacceptable clinical performances over long-term behavior (as compared to conventional composites) [7]. Recently, 
manufacturers introduced nano-hybrid ormocers in order to maintain high standards in the physicochemical properties of the materials $[1,2,8]$. According to the composition data provided, resin matrix consists of methacrylate-functionalized polysiloxanes with added silicate oxide. Manufacturers have stated that this asset of composition frees less unbound monomers, thus resulting in a higher biocompatibility of composite material [9-11]. The present study aimed to improve knowledge about the biocompatibility of different nanohybrid composite resins by testing their cytotoxicity on immortalized human gingival fibroblast-1 HGF-1 (ATCC CRL-2014) cell lines using cell viability assay.

\section{Materials and Methods}

Eight composites were selected for this study: Omnichroma (OC), Omnichroma Blocker (OCB), Admira Fusion x-tra (AFX), Enamel Plus HRi Bio Function Enamel (EPE), Enamel Plus HRi (EP), G-aenial (anterior) (GA), G-aenial Flo X (GFX), Enamel Plus HRi Bio Function Bio Dentine (EPD).

The specifications of the materials are listed in Table 1.

Table 1. Composite resins tested in this study.

\begin{tabular}{|c|c|c|c|c|c|}
\hline Material & Manufacturer & Code & Composition & $\begin{array}{c}\text { Filler } \\
\text { Content }\end{array}$ & Lot Number \\
\hline Omnichroma & $\begin{array}{l}\text { Tokuyama Dental } \\
\text { Corporation Tokyo, } \\
\text { Japan }\end{array}$ & $\mathrm{OC}$ & $\begin{array}{l}\text { Matrix: UDMA/TEGDMA } \\
\text { monomers } \\
\text { Filler: spherical } \mathrm{SiO}_{2}-\mathrm{ZrO}_{2}\end{array}$ & $79 \%(w / w)$ & 003M2 \\
\hline Omnichroma Blocker & $\begin{array}{l}\text { Tokuyama Dental } \\
\text { Corporation Tokyo, } \\
\text { Japan }\end{array}$ & OCB & $\begin{array}{l}\text { Matrix: Bis-GMA, triethylene } \\
\text { glycol dimethacrylate } \\
\text { Filler: spherical } \mathrm{SiO}_{2}-\mathrm{ZrO}_{2}\end{array}$ & $82 \%(w / w)$ & 002 \\
\hline Admira Fusion x-tra & $\begin{array}{l}\text { Voco, Cuxhaven, } \\
\text { Germany }\end{array}$ & AFX & $\begin{array}{l}\text { Matrix: ORMOCER }{ }^{\circledR} \\
\text { Filler: glass ceramics, silica } \\
\text { nanoparticles, pigments }\end{array}$ & $84 \%(w / w)$ & 1750435 \\
\hline $\begin{array}{c}\text { Enamel Plus HRi } \\
\text { Bio Function Enamel }\end{array}$ & $\begin{array}{l}\text { Micerium S.p.A., } \\
\text { Avegno, Italy }\end{array}$ & EPE & $\begin{array}{l}\text { Matrix: urethane dimethacrylate, } \\
\text { tricyclodecane dimethanol } \\
\text { dimethacrylate, no comonomers } \\
\text { and no Bis-GMA } \\
\text { Filler: glass filler, high dispersion } \\
\text { silicon dioxide, fluorine }\end{array}$ & $74 \%(w / w)$ & 2018006379 \\
\hline Enamel Plus HRi & $\begin{array}{l}\text { Micerium S.p.A., } \\
\text { Avegno, Italy }\end{array}$ & $\mathrm{EP}$ & $\begin{array}{l}\text { Matrix: diurethan dimethacrylate, } \\
\text { BisGMA, } \\
\text { 1,4-butandioldimethacrylate } \\
\text { Filler: surface-treated nano } \\
\text { zirconium oxide particles, glass }\end{array}$ & $77 \%(w / w)$ & 2017008768 \\
\hline G-ænial (Anterior) & $\begin{array}{l}\text { GC Corporation, } \\
\text { Tokyo, Japan }\end{array}$ & GA & $\begin{array}{l}\text { Matrix: UDMA, dimethacrylate } \\
\text { co-monomers, no bis-GMa } \\
\text { Filler: silica, strontium, } \\
\text { lanthanoid fluoride }\end{array}$ & $76 \%(w / w)$ & 190530A \\
\hline G-ænial Flo X & $\begin{array}{l}\text { GC Corporation, } \\
\text { Tokyo, Japan }\end{array}$ & GFX & $\begin{array}{l}\text { Matrix: UDMA, Bis-MPEPP), } \\
\text { TEGDMA } \\
\text { Filler: silicon dioxide, } \\
\text { strontium glass }\end{array}$ & $71 \%(w / w)$ & 190521A \\
\hline $\begin{array}{l}\text { Enamel Plus HRi } \\
\text { Bio Function } \\
\text { Bio Dentine }\end{array}$ & $\begin{array}{l}\text { Micerium S.p.A., } \\
\text { Avegno, Italy }\end{array}$ & EPD & $\begin{array}{l}\text { Matrix: urethane dimethacrylate, } \\
\text { tricyclodecane dimethanol } \\
\text { dimethacrylate, no comonomers } \\
\text { and no Bis-GMA } \\
\text { Filler: glass filler, high dispersion } \\
\text { silicon dioxide, fluorine }\end{array}$ & $74 \%(w / w)$ & 2018006379 \\
\hline
\end{tabular}




\subsection{Cell Culture}

Immortalized human gingival fibroblast-1 HGF-1 (ATCC CRL-2014) cell lines were obtained from the American Type Culture Collection and cultured in high-glucose Dulbecco's modified Eagle's medium (DMEM; Sigma-Aldrich, St. Louis, MO, USA) supplemented with $4 \mathrm{mM}$ L-glutamine (Sigma-Aldrich), 1\% penicillin, streptomycin (Sigma-Aldrich), and $10 \%(v / v)$ heat-inactivated fetal bovine serum (FBS; Sigma-Aldrich). Cells were incubated at $37^{\circ} \mathrm{C}$ in $5 \% \mathrm{CO}_{2}$ atmosphere, fed every $48 \mathrm{~h}$ and routinely subcultured every 5 days with a split ratio of 1:3 using trypsin-EDTA $\left(0.05 \%\right.$; Sigma-Aldrich) for $3 \mathrm{~min}$ at $37^{\circ} \mathrm{C}$.

\subsection{Sample Preparation}

Composite disc samples with a diameter of $7 \mathrm{~mm}$ and a height of $2 \mathrm{~mm}$ were prepared according to ISO 10993-12:2012 standards using customized molds, consistent with the manufacturers' instructions [12,13]. While condensation of the unpolymerized composite was achieved on a glass plate, a mylar matrix strip was applied on the surface to limit oxygen inhibition. Excess material was removed with a sterile scalpel. Polymerization was accomplished using an LED light source (Celalux 3, High-Power LED curing-light; VOCO, Cuxaven, Germany) at an average $720 \mathrm{~mW} / \mathrm{cm}^{2}$ for $40 \mathrm{~s}$, applied to bottom and top surfaces of the disc. The composite disc samples $(n=3)$ were then $U V$ sterilized prior to cytotoxicity testing. Excess material was removed with a sterile scalpel. To prevent contamination, specimens were exposed to UV light for $24 \mathrm{~h}$ after manipulation. Each composite was immersed in extraction medium immediately after setting.

\subsection{Preparation of the Extract}

The extraction was made by eluting the composites in cell culture medium (see cell culture paragraph) using a surface area-to-volume ratio of approximately $1.25 \mathrm{~cm}^{2} / \mathrm{mL}$ between the surface of the samples and the volume of medium [12]. The extraction vials were incubated at $37^{\circ} \mathrm{C}$ for $48 \mathrm{~h}$ or $72 \mathrm{~h}$. The specimens were then discarded, and the elute extracts were filtered by $0.22-\mu \mathrm{m}$-pore-sized membranes (Millipore; Billerica, MA, USA). Undiluted extracts were used for the cytotoxicity tests.

\subsection{Cytotoxicity Test}

Cells $\left(1 \times 10^{4}\right)$ were seeded in each well of a 96-well plate and incubated for $24 \mathrm{~h}$ at $37^{\circ} \mathrm{C}$. Cultures were then exposed to $100 \mu \mathrm{L}$ of the extract medium. Fresh cell medium was used as control. After $24 \mathrm{~h}$, cell viability was determined using MTT assay. The MTT solution-(3-\{4,5-dimethylthiazol-2-yl\}-2,5-diphenyl tetrazolium bromide) (Sigma-Aldrich) in RPMI-1640 without phenol red (Sigma-Aldrich) $(5 \mathrm{mg} / \mathrm{mL}$ ) — was added to each well of the culture plate to reach a final concentration of $0.5 \mathrm{mg} / \mathrm{mL}$, and the cells were incubated for $4 \mathrm{~h}$ at $37^{\circ} \mathrm{C}$. Then, the supernatant was removed and the resulting formazan was dissolved by adding $100 \mu \mathrm{L}$ DMSO (Sigma-Aldrich) to each well. The optical density of formazan dye was read at $545 \mathrm{~nm}$ against $620 \mathrm{~nm}$ as background by an Elisa reader (BioRad, Hercules, California, USA). The percentage of viable cells in each well was calculated relative to control cells set to $100 \%$. Cytotoxicity responses were rated as severe (30\%), moderate $(30-60 \%)$, mild $(60-90 \%)$ or noncytotoxic $(>90 \%)[4,5,10]$.

\subsection{Statistical Analysis}

The control group had a cytotoxicity volume of $0 \%$ and viability volume of $100 \%$. Data were analyzed with R (The R Foundation for Statistical Computing). The resulting data (Table 2) were expressed as percentages of cell viability rates, where the control group correlated to about $100 \%$. Descriptive statistic values-median, minimum, maximum, mean and standard deviation - were calculated. Data observed were not normally distributed and nonparametric statistical methods were used for statistical analysis. The Wilcoxon test was used for intragroup comparison, and the Kruskal-Wallis test was used for intergroup multiple comparisons. Significance value was set as $p<0.05$. 
Table 2. Statistical comparisons using Wilcoxon Test for each material after $48 \mathrm{~h}$ and $72 \mathrm{~h}$. Significance was set at 0.05 .

\begin{tabular}{|c|c|c|c|c|c|}
\hline \multirow[t]{2}{*}{ Material } & \multicolumn{2}{|c|}{$48 \mathrm{~h}$} & \multicolumn{2}{|c|}{$72 \mathrm{~h}$} & \multirow[b]{2}{*}{$p$} \\
\hline & Median (Max-Min) & Mean (SD) & Median (Max-Min) & Mean (SD) & \\
\hline Control & $99(102-96)$ & $98.8(1.61)$ & $98.5(101-96)$ & $98.4(1.50)$ & 0.448 \\
\hline Omnichroma & $88(93-82)$ & $87.6(3.14)$ & $74.5(83-70)$ & $75.35(3.67)$ & 0.000 \\
\hline Omnichroma Blocker & $85.5(90-81)$ & $85.8(2.80)$ & $75(85-67)$ & $74.65(4.66)$ & 0.000 \\
\hline Admira Fusion $\mathrm{x}$-tra & $84.5(89-79)$ & $84.3(3.19)$ & $61.5(69-56)$ & $61.85(4.22)$ & 0.000 \\
\hline $\begin{array}{c}\text { Enamel Plus HRi Bio } \\
\text { Function Enamel }\end{array}$ & $86(91-81)$ & $86.2(2.71)$ & $62.5(68-53)$ & $61.5(4.5)$ & 0.000 \\
\hline Enamel Plus HRi & $28(31-18)$ & $27,1(3.6)$ & $27.5(38-21)$ & $28.55(4.85)$ & 0.794 \\
\hline G-aenial (Anterior) & $53(65-39)$ & $53.05(5.52)$ & $52.5(59-44)$ & $51.75(4.63)$ & 0.400 \\
\hline G-aenial Flo X & $47.5(55-39)$ & $46.9(4.14)$ & $36.5(48-29)$ & $37.15(5.19)$ & 0.000 \\
\hline $\begin{array}{l}\text { Enamel Plus HRi Bio } \\
\text { Function Bio Dentine }\end{array}$ & $44.5(52-38)$ & $44.35(4.2)$ & $36.5(46-32)$ & $37.55(4.1)$ & 0.000 \\
\hline
\end{tabular}

\section{Results}

The Wilcoxon test for intragroup comparison showed that, after $72 \mathrm{~h}$ of incubation, the cell viability rates were significantly lower than after $48 \mathrm{~h}$ of incubation for all the composite resins tested except for Enamel Plus HRi and G-aenial (Figures 1 and 2). However, Enamel Plus HRi and G-aenial showed, respectively, severe and moderate toxicity after $48 \mathrm{~h}$. The cell viability rates maintained equally after $72 \mathrm{~h}$. After $48 \mathrm{~h}$, Omnichroma, Omnichroma Blocker, Admira Fusion x-tra, and Enamel Plus HRi Bio Function Enamel showed the lowest grade of cytotoxicity (cell viability $>80 \%$ ) and no significant differences were recorder for intergroup multiple comparisons with Kruskal Wallis test (Figure 3). After $72 \mathrm{~h}$ Omnichroma and Omnichroma Blocker showed a comparable mild cytotoxicity (Kruskal Wallis $p>0.05$ ), with a significant decrease in cell viability rates as compared to data after $48 \mathrm{~h}$ (Wilcoxon $p<0.05$ ). Admira Fusion $\mathrm{x}$-tra and Enamel Plus HRi Bio Function Enamel showed a significant reduction to moderate cytotoxicity and cell viability rates were comparable with Kruskal Wallis test after $72 \mathrm{~h}(p>0.05)$. G-aenial Flo X and Enamel Plus HRi Bio Function Bio Dentine showed similar results after $48 \mathrm{~h}$ and $72 \mathrm{~h}$ (Kruskal-Wallis $p>0.05$ ). Both the composite resins showed a lower cell viability rate after $72 \mathrm{~h}$ as compared to $48 \mathrm{~h}$ immersion (Wilcoxon $p<0.05$ ). 


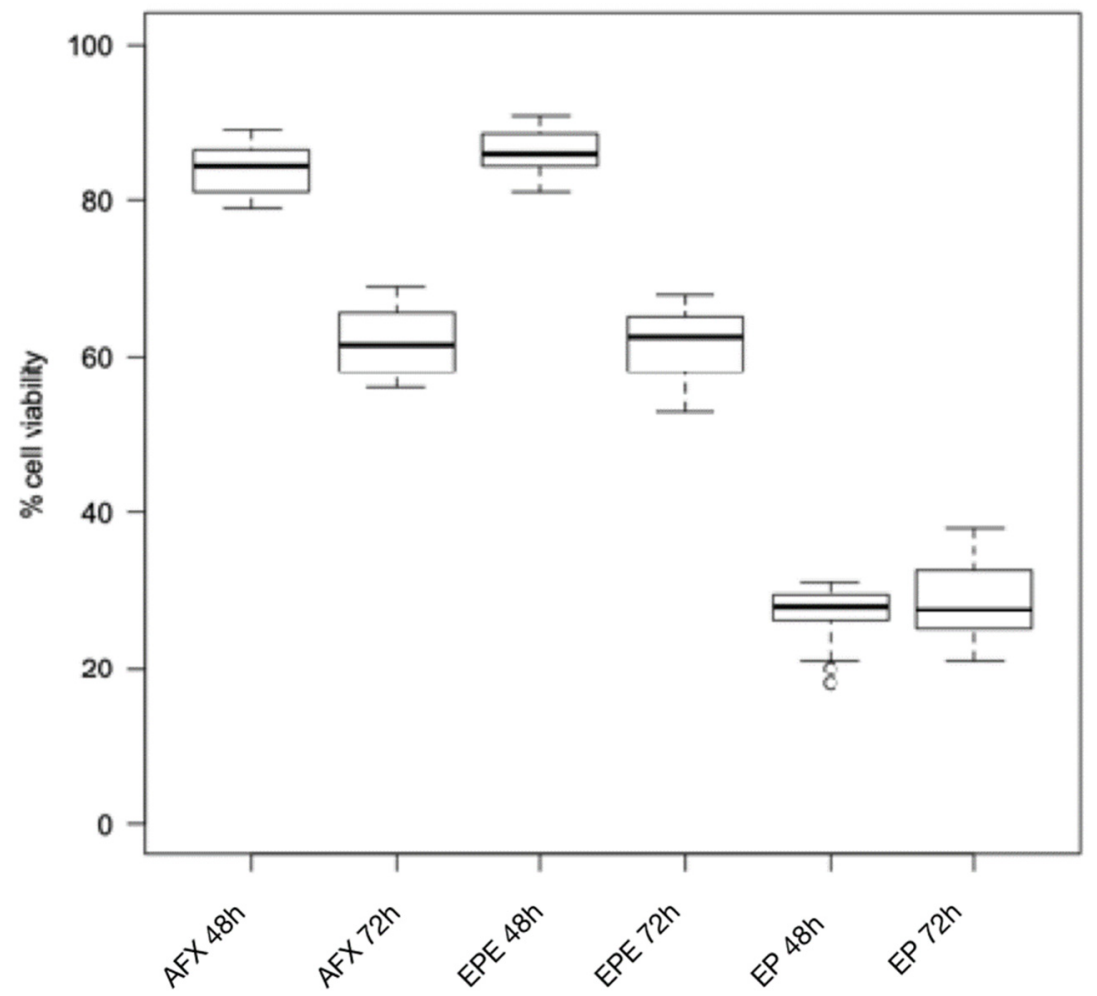

Figure 1. Cytotoxicity of composite resins on human gingival fibroblast cell lines after $24 \mathrm{~h}$ and $48 \mathrm{~h}$. AFX: Admira Fusion x-tra; EPE: Enamel Plus HRi Bio Function Enamel; EP: Enamel Plus HRi.

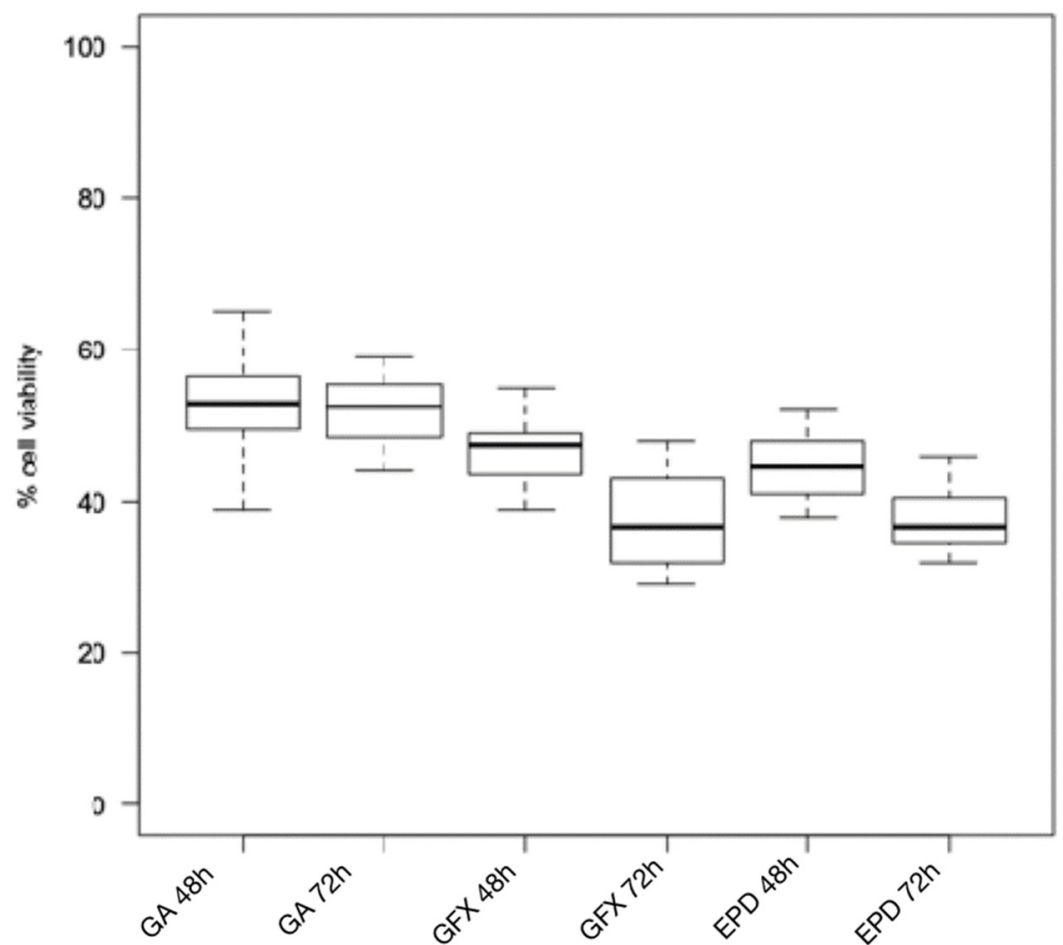

Figure 2. Cytotoxicity of composite resins on human gingival fibroblast cell lines after $24 \mathrm{~h}$ and $48 \mathrm{~h}$. GA: G-ænial (Anterior); GFX: G-ænial Flo X; EPD: Enamel Plus HRi Bio Function Bio Dentine. 


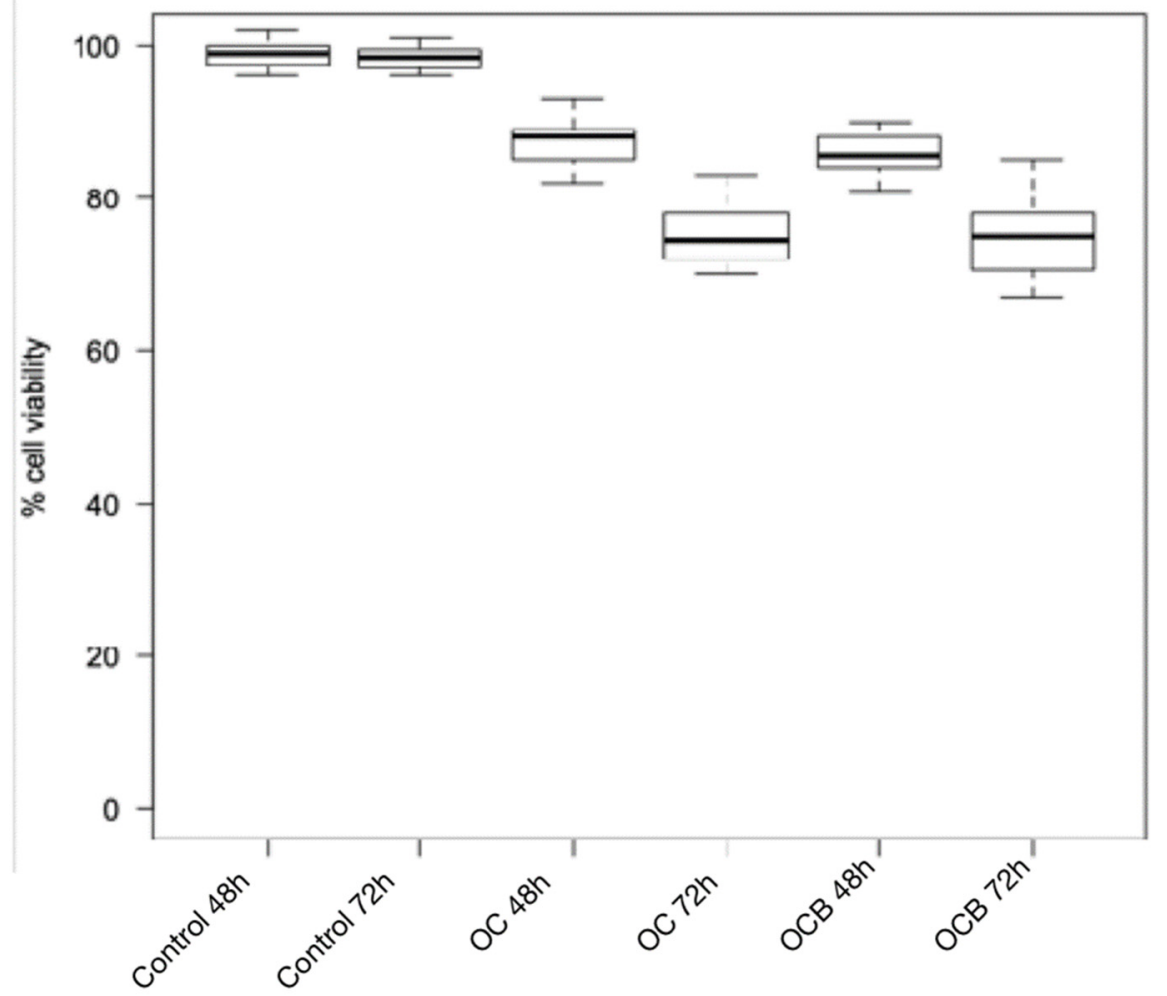

Figure 3. Cytotoxicity of composite resins on human gingival fibroblast cell lines after $24 \mathrm{~h}$ and $48 \mathrm{~h}$. OC: Omnichroma; OCB: Omnichroma Blocker.

\section{Discussion}

Several authors have demonstrated that tooth restorations produce an inflammatory response in soft tissues adjacent to the restorative material [14-16]. The healthy oral tissue is covered by squamous epithelia of keratinocytes, and the connecting tissue underneath is formed by gingival fibroblasts. Over time, aesthetic demands from patients drew attention to issues regarding the inflammatory conditions of periodontal tissues in contact with dental restorations. The importance of biocompatibility of the dental material is crucial in cases of deep subgingival caries and abrasive defects of the root after gingival recessions. The aesthetic limits of resin-based materials were even correlated to unsatisfactory long-term durability of restorations due to secondary caries and microleakage. Composite resins have been reinforced with higher amounts of filler and different-sized filler particles. Manufacturers developed nano-hybrid composites with reduced free unbound monomers and higher amounts of silicate oxide, thus improving the physical properties of the composite resins. However, biocompatibility remains the key factor in the success or failure of restorations in many clinical cases. The importance of testing the ultimate composite resins and their components in vitro cannot be overstated; such tests allow the clinician to choose the best-suited material in every clinical case, avoiding inflammation of periodontal tissue and rapid decay of tooth restorations.

The principle of the direct contact in vitro test used to assess the biocompatibility of restorative materials is the direct contact between cell lines and the material, similarly to what happens in clinical situations. The effects of the monomers released after polymerization on the surrounding tissues is surface-dependent. In a validly reproduced direct contact test, sample surface area and culture medium volume will have an impact on the results [17]. In one study, the sample surface area of each disc was about $120 \mathrm{~mm}^{2}$ wider than the mean surface area in clinical fillings. Monitoring the molecular processes and cellular viability over a chosen time made it possible to determine the cytotoxicity of composite resins [12]. Several authors have stated that the direct contact test provided more sensitive results in the determination of material toxicity $[18,19]$. 
The present study aimed to compare (in vitro) the impact of nano-hybrid composites and composite resins on human fibroblasts. The limited results found in the literature did not clarify how composition influenced cytotoxic effects. Nano-hybrid ormocers release fewer monomers and show less cytotoxicity [20-22]. Yang et al. [20] found the lowest cytotoxicity on human fibroblasts in nano-hybrid ormocer groups. In our study, we found that Omnichroma and Omnichroma Blocker had a significantly lower cytotoxicity after $72 \mathrm{~h}$ of direct contact between the material and human fibroblasts. Continuous release of free monomers was registered for Admira Fusion x-tra and Enamel Plus HRi Bio Function Enamel. Cell viability rates decreased significantly between the first registration of the cell viability rate (after $48 \mathrm{~h}$ ) and the second registration (after $72 \mathrm{~h}$ ). An incomplete conversion from monomers to polymers could have been the cause of the decrease of cell viability rate observed. The degree of conversion from monomers to polymers depends on curing time $[23,24]$. Therefore, we assumed that the polymerization time $(40 \mathrm{~s})$ that we applied led to an even higher degree of conversion for ormocer composite materials and, consequently, to decreased cellular toxicity compared to Enamel Plus HRi, G-aenial (anterior), G-aenial Flo X, and Enamel Plus HRi Bio Function Bio Dentine, all of which exhibited a lower degree of conversion [25]. Additionally, the composite materials studied differed significantly in filler degree (Table 1). A high filler degree in a resin-based dental composite positively influences its physicomechanical properties [26]. Moreover, it minimizes the organic matrix, which improves the material's biocompatibility [25]. The absence of classic resin monomers in Omnichroma, Omnichroma Blocker, Admira Fusion x-tra, and Enamel Plus HRi Bio Function Enamel apparently resulted in lower cytotoxicity levels and better biocompatibility compared to resin-based dental restorative materials. This may be of great importance for clinical use. A continuous release of monomers could be registered in further studies with longer experimental periods. Even if human cell viability and growth seem to be affected in the short term, a longer experimental period could help to investigate the chronic effects of unbound monomers on human cell lines [27]. The moderate-severe cytotoxicity expressed at the contact between resin-based composites and human gingival fibroblasts could increase if the duration of exposure were to increase in relation to the cumulative effect caused by continuous monomer release from the materials [27]. The contact between composite resins and human gingival fibroblasts in subgingival areas should be further investigated. However, this in vitro study-based on direct contact between restorative materials and human gingival fibroblasts-seemed to clarify the mechanisms of inflammation of periodontal tissues.

\section{Conclusions}

In this study, using MTT assay, we demonstrated that composite resins used for tooth restorations have different biocompatibility standards that depend mainly on composition and percentage of unbound monomers. Ceramic fillers-recently included in some restorative materials - could improve biocompatibility because less monomer is required to obtain a performant dental material. Clinicians should consider the inflammation that restorative materials could cause to surrounding periodontal tissue and consequently choose products that promote less cytotoxicity.

Author Contributions: Conceptualization, C.P.; Data curation, R.B., K.R. and A.D.C.; Investigation, R.B., M.C., K.R. and G.P.; Resources, M.C., C.P. and A.D.C.; Software, R.B. and G.P.; Supervision, C.P.; Validation, C.P., G.P.; Writing-original draft, R.B. and M.C.; Writing-Review \& Editing, C.P., G.P. All authors have read and agreed to the published version of the manuscript.

Funding: This study did not receive any grants.

Institutional Review Board Statement: Not applicable.

Informed Consent Statement: Not applicable.

Data Availability Statement: The data presented in this study are available on request from the corresponding author. 
Acknowledgments: Nothing to declare.

Conflicts of Interest: The authors declare no conflict of interest.

\section{References}

1. Fleming, G.J.; Hall, D.P.; Shortall, A.C.; Burke, F.J. Cuspal movement and microleakage in premolar teeth restored with posterior filling materials of varying reported volumetric shrinkage values. J. Dent. 2005, 33, 139-146. [CrossRef]

2. Lutz, F.; Krejci, I. Amalgam substitutes: A critical analysis. J. Esthet. Dent. 2000, 12, 146-159. [CrossRef]

3. Ferracane, J.L. Elution of leachable components from composites. J. Oral. Rehabil. 1994, 21, 441-452. [CrossRef] [PubMed]

4. Goldberg, M. In vitro and in vivo studies on the toxicity of dental resin components: A review. Clin. Oral Investig. 2008, 12, 1-8. [CrossRef] [PubMed]

5. Geurtsen, W.; Lehmann, F.; Spahl, W.; Leyhausen, G. Cytotoxicity of 35 dental resin composite monomers/additives in permanent 3T3 and three human primary fibroblast cultures. J. Biomed. Mater. Res. 1998, 41, 474-480. [CrossRef]

6. Mahmoud, S.H.; El-Embaby, A.E.; AbdAllah, A.M. Clinical performance of ormocer, nanofilled, and nanoceramic resin composites in class I and class II restorations: A three-year evaluation. Oper. Dent. 2014, 39, 32-42. [CrossRef] [PubMed]

7. Monsarrat, P.; Garnier, S.; Vergnes, J.N.; Nasr, K.; Grosgogeat, B.; Joniot, S. Survival of directly placed ormocer-based restorative materials: A systematic review and meta-analysis of clinical trials. Dent. Mater. 2017, 33, e212-e220. [CrossRef] [PubMed]

8. Gregor, L.; Dorien, L.; Bortolotto, T.; Feilzer, A.J.; Krejci, I. Marginal integrity of low-shrinking versus methacrylate-based composite: Effect of different one-step self-etch adhesives. Odontology 2016, 1, 55-59. [CrossRef] [PubMed]

9. Moszner, N.; Gianasmidis, A.; Klapdohr, S.; Fischer, U.K.; Rheinberger, V. Sol-gel materials 2. Light-curing dental composites based on ormocers of cross-linking alkoxysilane methacrylates and further nano-components. Dent. Mater. 2008, 24, 851-856. [CrossRef]

10. Al-Hiyasat, A.S.; Darmani, H.; Milhem, M.M. Cytotoxicity evaluation of dental resin composites and their flowable derivatives. Clin. Oral Investig. 2005, 9, 21-25. [CrossRef] [PubMed]

11. Susila, A.V.; Balasubramanian, V. Correlation of elution and sensitivity of cell lines to dental composites. Dent. Mater. 2016, 32, e63-e72. [CrossRef]

12. Cao, T.; Saw, T.Y.; Heng, B.C.; Liu, H.; Yap, A.U.; Ng, M.L. Comparison of different test models for the assessment of cytotoxicity of composite resins. J. Appl. Toxicol. 2005, 25, 101-108. [CrossRef]

13. Saw, T.Y.; Cao, T.; Yap, A.U.; Lee Ng, M.M. Tooth slice organ culture and established cell line culture models for cytotoxicity assessment of dental materials. Toxicol. Vitr. 2005, 19, 145-154. [CrossRef]

14. Van Dijken, J.W.; Sjöström, S.; Wing, K. Development of gingivitis around different types of composite resin. J. Clin. Periodontol. 1987, 14, 257-260. [CrossRef]

15. Paolantonio, M.; D'ercole, S.; Perinetti, G.; Tripodi, D.; Catamo, G.; Serra, E.; Bruè, C.; Piccolomini, R. Clinical and microbiological effects of different restorative materials on the periodontal tissues adjacent to subgingival class $\mathrm{V}$ restorations: 1-year results. J. Clin. Periodontol. 2004, 31, 200-207. [CrossRef] [PubMed]

16. Santos, V.R.; Lucchesi, J.A.; Cortelli, S.C.; Amaral, C.M.; Feres, M.; Duarte, P.M. Effects of glass ionomer and microfilled composite subgingival restorations on periodontal tissue and subgingival biofilm: A 6-month evaluation. J. Periodontol. 2007, 78, 1522-1528. [CrossRef] [PubMed]

17. Franz, A.; Konig, F.; Skolka, A.; Sperr, W.; Bauer, P.; Lucas, T.; Watts, D.C.; Schedle, A. Cytotoxicity of resin composites as a function of interface area. Dent. Mater. 2007, 23, 1438-1446. [CrossRef] [PubMed]

18. De Melo, W.M.; Maximiano, W.M.A.; Antunes, A.A.; Beloti, M.M.; Rosa, A.L.; de Oliveira, P.T. Cytotoxicity testing of methyl and ethyl 2-cyanoacrylate using direct contact assay on osteoblast cell cultures. J. Oral Maxillofac. Surg. 2013, 71, 35-41. [CrossRef] [PubMed]

19. Li, W.; Zhou, J.; Xu, Y. Study of the in vitro cytotoxicity testing of medical devices. Biomed. Rep. 2015, 3, 617-620. [CrossRef]

20. Yang, Y.; Reichl, F.-X.; Shi, J.; He, X.; Hickel, R.; Högg, C. Cytotoxicity and DNA double-strand breaks in human gingival fibroblasts exposed to eluates of dental composites. Dent. Mater. 2018, 34, 201-208. [CrossRef] [PubMed]

21. Anand, V.S.; Balasubramanian, V. Effect of resin chemistry on depth of cure and cytotoxicity of dental resin composites. Mater. Sci. Eng. B. 2014, 181, 33-38. [CrossRef]

22. Khurshid, Z.; Zafar, M.; Qasim, S.; Shahab, S.; Naseem, M.; AbuReqaiba, A. Advances in nanotechnology for restorative dentistry. Materials 2015, 16, 717-731. [CrossRef]

23. Manojlovic, D.; Radisic, M.; Vasiljevic, T.; Zivkovic, S.; Lausevic, M.; Miletic, V. Monomer elution from nanohybrid and ormocer-based composites cured with different light sources. Dent. Mater. 2011, 27, 371-378. [CrossRef] [PubMed]

24. Amato, P.A.; Martins, R.P.; dos Santos Cruz, C.A.; Capella, M.V.; Martins, L.P. Time reduction of light curing: Influence on conversion degree and microhardness of orthodontic composites. Am. J. Orthod. Dentofac. Orthop. 2014, 146, 40-46. [CrossRef] [PubMed]

25. Caughman, W.F.; Caughman, G.B.; Shiflett, R.A.; Rueggeberg, F.; Schuster, G.S. Correlation of cytotoxicity, filler loading and curing time of dental composites. Biomaterials 1991, 12, 737-740. [CrossRef]

26. Randolph, L.D.; Palin, W.M.; Leloup, G.; Leprince, J.G. Filler characteristics of modern dental resin composites and their influence on physico-mechanical properties. Dent. Mater. 2016, 32, 1586-1599. [CrossRef] [PubMed]

27. Putzeys, E.; De Nys, S.; Cokic, S.M.; Duca, R.C.; Vanoirbeek, J.; Godderis, L.; Van Meerbeek, B.; Van Landuyt, K.L. Long-term elution of monomers from resin-based dental composites. Dent. Mater. 2019, 35, 477-485. [CrossRef] [PubMed] 